\title{
Lembar Kerja Document Base Test
}

Dikerjakan oleh $\quad$ : Khairudi

NIM $\quad: 1910111210035$

\section{Hasil analisis untuk pernyataan 1}

a. Karena sistem ekonomi di indonesia lebih cenderung kepada sebuah sistem ekonomi kerakyatan Dan ide dari ekonomi sosialis indonesia sendiri perwujudan dari sistem ekonomi tradisional Indonesia yang sangat mengutamakan ekonomi kerakyatan. Dan masyarakat inya sendiri memiliki ciri tersendri aitu mengutamakan saling tolong menolong dimana sikap tersebut sudah menjadi budaya masyarakat tradisonal zaman dulu dan berkemabang sampai sekarang Keadaan ini menyebabkan masyarakat meninggalkan budaya ekonomi kolektif yang telah terbukti efektif dalam tatanan ekonomi tradisional Indonesia. Oleh karenanya cita-cita sosialisme Indonesia pada dasarnya adalah berusaha mempertahankan jiwa kolektif tersebut sebagai sendi bangunannya sehingga terbenyuk hal koperasi sebai peranan openting dalam sebuah ekonomi Dari pemahaman tersebut bahwa Oleh sebab itu sistem ekonomi tradisioanal indonesia dikatakan juga sebagai sistem ekonomi ala indoensia.

b. Corak ekonomi indoensia sendiri tidak lepas dari perkembangan dari kebudayaan indoensia karena bahwasanya kebudayaan merupakan peranan yang cukup penting di dalam mendukung kinerja perekonomian karena terkait dengan pembentukan kepercayaan di dalam kelompok sehingga mengurangi biaya transaksi. Dengan adanya peranan perkembagan kebudayaan kinerja perekonomian akan lebih terlihat perkembanganya. Oleh sebab itu hubungan antara corak ekonomi indonesia dengan perkembangan kebudayaan indonesia tidak bisa dipisahkan karena memiliki keterkaitan satu sama lain

c. Keterkaitan nya yaitu dari kemunculnya di dimana disebabkan oleh tidak dipecahkannya masalah kemisikinan atas dasar semangat individualisme. Koperasi ini lahir atas persoalan tentang kemiskianan oleh sabab itu koperasi sebgai alat untuk mengatasi kepincangan-kepincang dan kelemahan -kelemahan dari perekonomian. Koperasi ini memang lahir karena adanya penderitan yang terjadi kepada masyarakat eropa saat itu . Sama dengan di indoneisa koperasi lahir sebagai usaha untuk memperbaiki ekonomi masyarakat yang dimana saat itu ditindas oleh penjajah 


\section{Hasil analisis untuk pernyataan 2}

a. Ciri-ciri koperasi indoensia yaitu kegiatan koperasi nya beradasarkan atas prinsip-prinsip koperasi yakni dalam pengembangannya dilaksanakan dengan bekerja sama dan bergotong royong berdasarkan persamaan derajat. Hak dan kewajiban dalam ruang lingkup koperasi hal itu sama dengan sikap ekonomi tradisonal indoneisa yaitu budaya saling tolong menolog dan bekerja sama yang merupakan wadah ekonomi dan sosial. Kemudian ciri selanjutnya yaitu bahwa koperasi indoenias berdarakan atas azas-azas kekeluargaan dan kegiatnya dilaksankan secara atas kesadaran anggotanya tanpa ada paksaaan

b. Ide nasakom ini menjadikan acuan dalam ekonomi di indonesia terutama ekonomi sosialis dimana ide tersebut sebagai pondasi dalam acuan perkembangan koperasi di indoenisa dimana didalam dekrit yang dikeluarkan presiden tersebut memuat tentang koperasi dengan adanya nasakom ini koperasi bisa berkembang dan megembangkan oraganisasi nya dalam peningkatan ekonomi. Dimana pemerintah memiliki peranan penting dalam perkembangan dan pengembangan koperasi Dengan demikian ide nasakom ini dimana pemerintah lah yang aktif dalam membina gerakan koperasi indonesia dengan asas-asas demokrasi terpimpin, yaitu menumbuhkan, mendorong, membimbing, melindungi dan mengawasi perkembangan Koperasi.

\section{Referensi}

Susanto, H. WAJAH SOSIALISME DALAM PERKEMBANGAN KOPERASI. 